\title{
EVALUASI PEMBELAJARAN SEKOLAH DASAR (SD) BERBASIS PENDIDIKAN KARAKTER DAN MULTIKULTURAL
}

\author{
Ivo Basri K. 1, \\ 1) Program Studi Pendidikan Guru Sekolah Dasar. Universitas Muhammadiyah Kupang
}

\begin{abstract}
Abstrak
Learning evaluation is the overarching concept which both depends upon measurements and assessment to make a composite judgment or decision. Character education and multicultural learning evaluation in elementary school (SD) adjusted with level thinking of the children in elementary school. Where there are still in early stages of the abstract. Character education is a system of cultivation of character values to the school community, which includes knowledge, awareness or volition, and actions to implement these values, both of the Almighty God (Almighty), ourselves, others, the environment, and national so that the perfect man to be human. While, indeed multicultural education becomes an integral part in all levels of education. Therefore the value investment multicultural ideally applied in all of subjects at formal education.
\end{abstract}

Keywords:

learning evaluation,

Elementary School,

character education, multicultural

\section{Pendahuluan}

Dalam rangka mengembangkan pendidikan di Indonesia pada era globalisasi, ada lima landasan yang harus digunakan sebagai rujukan yaitu landasan filosofi, landasan sosiologis, landasan kultural, landasan psikologis, dan landasan ilmiah dan teknologi serta didukung oleh tiga azas pembelajaran yaitu azas Tut Wuri Handayani, azas belajar sepanjang hayat, dan azas kemandirian dalam belajar (Umar Tirtarahardja: 2005). Pendidikan nasional bertujuan mengembangkan kemampuan dan membentuk watak serta peradaban bangsa yang bermatabat dalam rangka mencerdaskan kehidupan bangsa (Hasbullah, 2009). Untuk mencapai tujuan pendidikan nasional, berbagai upaya dilakukan untuk mecapai tujuan tersebut, mulai dari pelatihan untuk meningkatkan kualitis guru, perbaikan sarana dan prasarana pendidikan dan penyempurnaan kurikulum secara periodic (Widiana, 2016). Sekolah adalah salah satu pendidikan formal yang diadikan sebagai saran untuk meningkatkan kualitas sumber daya manusia. Proses pendidikan dimulai dari proses perencanaan pengajaran hingga tahap evaluasi.

Evaluasi merupakan proses penilaian pencapaian tujuan dan pengungkapan masalah kinerja program/kegiatan untuk memberikan umpan balik bagi peningkatan kualitas kinerja program/kegiatan ( Divayana, 2016). Dalam proses pembelajaran, evaluasi merupakan bagian yang amat penting. Evaluasi dapat memberi gambaran tentang tingkat penguasaan siswa terhadap satu materi, memberi gambaran tentang kesulitan belajar siswa, dan memberi gambaran tentang posisi siswa di antara kawan-kawannya (Setemen, 2010). Evaluasi adalah proses penggambaran dan penyempurnaan informasi yang berguna untuk menetapkan alternatif. Alternatif evaluasi bisa mencakup arti pengukuran dan penilaian dalam pembelajaran. Dengan demikian evaluasi pembelajaran merupakan kegiatan yang lebih kompleks dibandingkan dengan pengukuran dan penilaian. Hasil evaluasi pembelajaran dapat memberi keputusan yang professional. Artinya, evaluasi pembelajaran merupakan satu kompetensi professional seorang pendidik. Kompetensi tersebut sejalan dengan instrumen penilaian kemampuan guru, yang salah satu indikatornya adalah melakukan evaluasi pembelajaran (Asrul., dkk, 2015).

Evaluasi pembelajaran pada tingkat Sekolah Dasar (SD) dapat diketahui guru dengan cara mengevaluasi peserta didik yaitu mengetahui ciri-ciri intelegentnya, salah satunya adalah evaluasi dilakukan secara tidak langsung pada peserta didik (Sari, 2014), berupa: (a) kemampuan untuk bekerja dalam bilangan, (b) kemampuan untuk menggunakan bahasa dengan baik, (c) kemampuan untuk menangkap sesuatu yang baru (cepat mengikuti pembicaraan orang lain), (d) kemampuan untuk mengingat-ingat, (e) kemampuan untuk memahami hubungan (termasuk menangkap kelucuan), dan (f) kemampuan berfantasi. Namun, ciri-ciri tersebut ada yang lebih mutakhir, berupa: (a) kemampuan verbal, (b) kemampuan mengamati dan rasa ruang, (c) kemampuan gerak kinetis-fisik, (d) kemampuan logika, (e) 
kemampuan dalam hubungan intra-personal, (f) kemampuan dalam hubungan inter-personal, dan kemampuan dalam irama. Kemampuan-kemampuan peserta didik tersebut sangat mudah diamati serta dievaluasi apabila dikaji dari pendidikan karakter dan multikulturalnya. Oleh karena itu, pendidikan karakter perlu ditingkatkan intensitas dan kualitasnya pada semua jalur dan jenjang pendidikan, melalui pengintegrasian ke dalam seluruh mata pelajaran di sekolah. Pendidikan karakter adalah suatu sistem penanaman nilai-nilai karakter kepada "warga" sekolah yang meliputi komponen pengetahuan, kesadaran atau kemauan, dan tindakan untuk melaksanakan nilai-nilai tersebut, baik terhadap Tuhan Yang Maha Esa (YME). diri sendiri, sesama, lingkungan, maupun kebangsaan sehingga menjadi manusia insan kamil (Saiffurrohman, 2014). Melalui pendekatan multikultur, pembelajaran yang dikembangkan oleh guru lebih menempatkan siswa dalam iklim pembelajaran yang memungkinkan mereka memadukan berbagai spektrum pengalaman belajar sehari-hari (di luar kelas) dengan berbagai spketrum pengalaman belajar di dalam kelas dalam latar yang alamiah (Sudiatmaka, 2012).

Pelaksanaan pendidikan karakter melalui pilar sekolah didasarkan atas tiga alasan penting yaitu: 1) Perlunya karakter yang baik untuk menjadi bagian yang utuh dalam diri manusia. Setiap manusia harus memiliki pikiran yang kuat, hati nurani, dan kemauan untuk berkualitas seperti memiliki kejujuran, empati, perhatian, disiplin diri, ketekunan dan dorongan moral; 2) Sekolah merupakan tempat yang baik dan kondusif untuk melaksanakan proses pembelajaran dan pendidikan nilai-nilai; dan 3) Pendidikan karakter sangat esensial untuk membangun masyarakat bermoral. Pendidikan karakter memiliki dua tujuan utama yaitu kebijakan dan kebaikan. Pendidikan tentang kebaikan merupakan dasar demokrasi, karena itu dua nilai moral penting yang harus diajarkan dalam pendidikan karakter adalah rasa hormat dan tanggung jawab (respect and responsibility). Pendidikan karakter diimplemantasikan dengan pembinaan karakter peserta didik. Cara pembinaan karakter adalah dalam materi pembelajaran yang harus diajarkan dan dikuasai serta direalisasikan oleh peserta didik dalam kehidupan sehari-hari. Permasalahannya, pendidikan karakter di sekolah selama ini baru menyentuh pada tingkatan pengenalan norma atau nilai-nilai dan belum pada tingkatan internalisasi dan tindakan nyata dalam kehidupan seharihari.

\section{Metode Penelitian}

Penelitian ini adalah library research (penelitian kepustakaan). Menurut Hasan (2013), penelitian kepustakaan yaitu penelitian yang dilaksanakan menggunakan literatur (kepustakaan), baik berupa buku, catatan, maupun laporan hasil penelitian dari penelitian terdahulu. Teknik pengumpulan data dalam penelitian ini adalah dengan menelaah jurnal hasil penelitian atau artikel ilmiah, buku, dokumen, atau informasi lain yang berhubungan dengan judul penelitian. Setelah data terkumpul selanjutnya dilakukan analisis data. Analisis data dalam penelitian ini adalah menganalisis dan mensintesis dokumen tersebut untuk dikaji dan menjadi gagasan baru dalam menunjang hasil penelitian.

\section{Hasil Dan Pembahasan}

Perkembangan baru terhadap pandangan pelaksanaan belajar mengajar membawa konsekuensi kepada guru untuk meningkatkan peranan dan kompetensinya, karena proses belajar mengajar dan hasil belajar peserta didik sebagian besar ditentukan oleh peran guru yang kompeten. Guru yang kompeten akan lebih mampu memciptakan lingkungan belajar yang efektif dan akan lebih mampu mengelola kelasnya, sehingga hasil belajar peserta didik berada pada tingkat optimal. Salah satu peran guru dalam proses belajar mengajar adalah sebagai evaluator. Dalam satu kali proses belajar mengajar guru hendaknya menjadi seorang evalutor yang baik. Kegiatan evaluasi pembelajaran dimaksudkan untuk mengetahui apakah tujuan yang telah dirumuskan itu tercapai atau belum, dan apakah materi yang diajarkan sudah cukup tepat. Semua pertanyaan tersebut akan dapat dijawab melalui kegiatan evaluasi pembelajaran. Kemudian evaluasi pembelajaran pendidikan dasar/tingkat Sekolah Dasar (SD) ditinjau dan dikaji dari pendidikan karakter dan multikultural peserta didik.

\section{Evaluasi Pembelajaran Pendidikan Dasar Berbasis Pendidikan Karakter}

Pendidikan karakter merupakan pembelajaran yang mengarah pada penguatan dan pengembangan perilaku peserta didik secara utuh yang didasarkan pada suatu nilai tertentu yang dirujuk oleh sekolah. Pendidikan karakter merupakan pendidikan yang terintegrasi dengan semua mata pelajaran. Pendidikan karakter berpandangan bahwa setiap peserta didik memiliki potensi untuk dikuatkan dan dikembangkan 
menjadi lebih baik. Nilai-nilai yang dirujuk di SD merupakan "alat" untuk menguatkan dan mengembangkan perilaku peserta didik.

Evaluasi pembelajaran pendidikan dasar berbasis pendidikan karakter, dengan cara penanaman nilai-nilai karakter yang dimasukkan dalam proses pembelajaran pada setiap mata pelajaran. Materi pembelajaran yang berkaitan dengan norma atau nilai-nilai pada setiap mata pelajaran perlu dikembangkan dan dihubungkan dengan konteks kehidupan sehari-hari melalui berbagai contoh nyata. Dengan kata lain, penanaman nilai karakter hendaknya dimulai dari keluarga dan sekolah. Melalui pendidikan karakter diharapkan peserta didik dapat tumbuh menjadi individu yang berkarakter mulia. Penanaman nilai-nilai karakter dapat diintegrasikan dalam evaluasi pembelajaran pada setiap mata pelajaran (Rinjani, 2017).

Hal tersebut dikarenakan dalam mempelajari materi yang berkaitan dengan norma atau nilainilai lebih mudah jika dikaitkan dengan konteks kehidupan sehari-hari melalui contoh yang lebih nyata. Kaitannya dengan pendidikan karakter adalah pembinaan akhlak. Melalui pendidikan karakter, pada diri peserta didik akan membentuk keseimbangan antara kecerdasan akademik, kecerdasaan emosional, dan kecerdasan spiritual. Fathurrohman, dkk (2013), menjelaskan bahwa manfaat yang diperoleh dari pendidikan karakter adalah peserta didik mampu mengatasi masalah pribadi sendiri, meningkatkan rasa tanggung jawab, meningkatkan prestasi akademik, dan meningkatkan suasana sekolah yang kondusif.

Adanya evaluasi pembelajaran berbasis pendidikan karakter bagi peserta didik SD bertujuan untuk meningkatkan mutu penyelenggaraan dan hasil pendidikan di sekolah yang mengarah pada pencapaian pembentukan karakter dan akhlak mulia peserta didik secara utuh, terpadu, dan seimbang, sesuai standar kompetensi lulusan. Melalui pendidikan karakter diharapkan peserta didik SD mampu secara mandiri meningkatkan dan menggunakan pengetahuannya, mengkaji dan menginternalisasi serta mempersonalisasi nilai-nilai karakter dan akhlak mulia sehingga terwujud dalam perilaku sehari-hari.

\section{Evaluasi Pembelajaran Pendidikan Dasar Berbasis Multikultural}

Pendidikan multikultural penting diberikan kepada peserta didik sejak dini. Hal itu penting dilaksanakan dengan harapan peserta didik mampu memahami bahwa di dalam lingkungan terdapat keragama budaya. Keragaman budaya mempengaruhi tingkah laku, sikap, pola pikir sehingga peserta didik memiliki cara-cara (usage), kebiasaan (folk ways), aturan-aturan (mores), dan adat istiadat (customs) yang berbeda satu sama lain. Oleh karena itu, menurut Syahid (2013), bahwa evaluasi pembelajaran pendidikan dasar berbasis multikultural diselenggarakan dalam upaya mengembangkan kemampuan peserta didik dalam memandang kehidupan dari berbagai perspektif budaya yang berbeda dengan budaya yang mereka miliki, dan bersikap positif terhadap perbedaan budaya, ras, dan etnis. Tujuan adanya evaluasi tersebut, antara lain: (1) untuk memfungsikan peranan sekolah dalam memandang keberadaan peserta didik yang beraneka ragam; (2) untuk membantu peserta didik dalam membangun perlakuan yang positif terhadap perbedaan kultural, ras, etnik, kelompok keagamaan; (3) memberikan ketahanan peserta didik dalam mengambil keputusan dan keterampilan sosialnya; dan (4) untuk membantu peserta didik dalam membangun ketergantungan lintas budaya dan memberi gambaran positif mengenai perbedaan kelompok. Selain itu, evaluasi pembelajaran berbasis multikultural dibangun atas dasar konsep pendidikan untuk kebebasan yang bertujuan untuk: (1) membantu peserta didik memiliki pengetahuan, sikap dan keterampilan untuk berpartisipasi di dalam demokrasi dan kebebasan masyarakat dan (2) memajukan kekebasan, kecakapan, keterampilan terhadap lintas batas-batas etnik dan budaya untuk berpartisipasi dalam beberapa kelompok dan budaya orang lain.

Adapun contoh konkritnya, penelitian yang telah dilakukan oleh Hanum dan Raharja (2016) di SD sebagai sasaran penelitian, agar nilai-nilai multikultural telah ditanamkan pada peserta didik sejak dini. Bila sejak awal peserta didik telah memiliki nilai-nilai kebersamaan, toleran, cinta damai, dan menghargai perbedaan, nilai-nilai tersebut akan tercermin pada tingkah laku peserta didik sehari-hari karena telah terbentuk pada kepribadiannya. Bila hal tersebut berhasil dimiliki para generasi muda, peserta didik dapat hidup dalam lingkungan yang damai sejahtera.

Nilai-nilai multikultural sangat penting diterapkan dalam pendidikan, karena nilai-nilai tersebut dapat mendidik dan mengajarkan peserta didik untuk bisa menghargai adanya perbedaan, menerima perbedaan, dan menghormati satu sama lain. Dalam proses pembelajaran, seorang guru harus bisa menanamkan nilai-nilai tersebut. Sehingga pesan dan nilai-nilai tersebut dapat masuk dan tumbuh kedalam diri setiap peserta didik. Nilai-nilai multikultural dalam pendidikan diharapkan dapat membentuk sikap peserta didik, untuk bisa menerima dan menghargai berbagai macam perbedaan yang ada disekitarnya (Baldah., dkk, 2016).

Pemaknaan nilai-nilai multikultural pada peserta didik di SD diperoleh setelah proses pengamatan, wawancara, interaksi dengan kepala sekolah, guru kelas, guru mata pelajaran dan peserta didik, pemahaman perilaku, ucapan-ucapan, serta tafsiran peserta didik tentang nilai-nilai multikultural. Dengan 
adanya evaluasi pembelajaran multikultural guru diharapkan mengetahui bagaimana berperilaku terhadap peserta didik yang bermacam-macam kulturnya di dalam kelas, dan mengetahui perbedaanperbedaan nilai-nilai, kultur dan bentuk-bentuk perilaku yang beraneka ragam. Selanjutnya menurut Hanum dan Raharja (2016), bahwa para peserta didik dapat menjadi generasi yang selalu menjunjung tinggi moralitas, kedisiplinan, kepedulian humanistik, dan kejujuran dalam berperilaku sehari-hari. Pada akhirnya, diharapkan bahwa permasalahan yang dihadapi bangsa lambat laun dapat diminimalkan. Generasi masa depan adalah generasi multikultural yang menghargai perbedaan, selalu menegakkan nilainilai demokrasi, keadilan dan kemanusiaan.

\section{Simpulan dan Saran}

Evaluasi pembelajaran merupakan satu kompetensi professional seorang pendidik. Kompetensi tersebut sejalan dengan instrumen penilaian kemampuan guru, yang salah satu indikatornya adalah melakukan evaluasi pembelajaran. Salah satu peran guru dalam proses belajar mengajar adalah sebagai evaluator bagi peserta didik. Oleh karena itu, Evaluasi Pembelajaran berbasis pendidikan karakter dan multikultural di tingkat sekolah dasar (SD) disesuaikan dengan tingkat perkembangan berpikir anak SD yang masih dalam taraf konkrit. Penanaman pendidikan karakter peserta didik hendaknya dimulai dari keluarga dan sekolah. Melalui pendidikan karakter diharapkan peserta didik dapat tumbuh menjadi individu yang berkarakter mulia. Penanaman nilai-nilai karakter dapat diintegrasikan dalam evaluasi pembelajaran pada setiap mata pelajaran. Sementara itu, pemaknaan nilai-nilai multikultural pada peserta didik di SD diperoleh setelah proses pengamatan, wawancara, interaksi dengan kepala sekolah, guru kelas, guru mata pelajaran dan peserta didik, pemahaman perilaku, ucapan-ucapan, serta tafsiran peserta didik tentang nilai-nilai multikultural.

\section{Daftar Pustaka}

Asrul., Ananda, R., dan Rosnita. 2015. Evaluasi Pembelajaran. Bandung: Citapustaka Media.

Baldah, W., Sumarna, C., Yuniarto, B. 2016. Pengaruh Penanaman Nilai-Nilai Multikultural terhadap Pembentukan Sikap Pluralis Peserta didik di MTsN Babakan Ciwaringin Kabupaten Cirebon. Jurnal Edueksos, V (1). Yogyakarta.

Divayana, Dewa Gede Hendra, Gusti Ayu Dessy Sugiharni. 2016. Evaluasi Program Sertifikasi Komputer Pada Universitas Teknologi Indonesia Menggunakan Model Cse-Ucla. Jurnal Pendidikan Indonesia Universitas Pendidikan Ganesha Volume 5 Nomor.

Fathurrohman, H.P., Suryana, A., dan Fatriani, F. 2013. Pengembangan Pendidikan Karakter. Bandung: PT Refika Aditama.

Hanum, F dan Raharja, S. 2016. Pengembangan Model Pembelajaran Multikultural Terintegrasi Mata Pelajaran IPS di Sekolah Dasar. Jurnal Penelitian Ilmu Pendidikan, VI (2). Universitas Negeri Yogyakarta: Yogyakarta.

Hasan, M. I. 2013. Pokok-Pokok Materi Metodologi Penelitian. Jakarta: Ghalia Indonesia.

Hasbullah. 2009. Dasar-Dasar Ilmu Pendidikan. Jakarta: Penerbit Bumi Pers.

Rinjani, E. D. 2017. Pendidikan Karakter Berbasis Multikultural dalam Pembelajaran Bahasa Indonesia sebagai Upaya Menghadapi Era Masyarakat Ekonomi Asean (MEA). Education and LanguageInternational Conference Proceedings Center for International Language Development of Unissula. Universitas Wahid Hasyim Semarang.

Saiffurrohman. 2014. Pendidikan Berbasis Karakter. Jurnal Tarbawl, II (2). ISSN: 2088-3102.

Sangadji, K. 2016. Pendidikan Multikultural dalam Pengembangan Kurikulum Perguruan Tinggi (sebuah Kajian Kurikulum). Jurnal Biologi Sel, V (1). Ambon: Fakultas Ilmu Tarbiyah dan Keguruan IAIN Ambon.

Sari, D. I. 2014. Evaluasi Pembelajaran. Jakarta. 
Setemen, Komang. 2010. Pengembangan Evaluasi Pembelajaran Online. Jurnal Pendidikan dan Pengajaran, Universitas Pendidikan Ganesha Jilid 43, Nomor 3, Oktober 2010, hlm.207-21.

Syahid, A. 2013. Aplikasi Pembelajaran Berwawasan Multikultural di Sekolah Dasar Muhammadiyah 3 Palu. Jurnal Penelitian Ilmiah ISTIQRA, I (1). ISSN: 2338-025X.

Sudiatmaka, K. dan W. Lasmawan. 2012. Pengembangan Model Pendidikan Multikultur Berbantuan Modul Berbasis Masalah Yang Berorientasi Pada Spiritualisme Dalam Pembelajaran IPS - SD. Jurnal Pendidikan Indonesia Universitas Pendidikan Ganesha, Volume 1 No 1.

Umar Tirtarahardja dan La Sulo.S.L. (2005). Pengantar Pendidikan. Jakarta: PT. Rineka Cipta.

Widiana, I Wayan. 2016. Pengembangan Asesmen Proyek Dalam Pembelajaran IPA Di Sekolah Dasar. Jurnal Pendidikan Indonesia Universitas Pendidikan Ganesha Volume 5 No 2. 